\title{
Effects of Temperature and Growing Seasons on Crop Water Requirement: Implications on Water Savings
}

\section{*1ABDULLAH, ABBAS; SHAKHAWAT, CHOWDHURY*}

Department of Civil and Environmental Engineering, Water Resources Group, King Fahd University of Petroleum and Minerals, Dhahran, Saudi Arabia; Tel: 966-13-860-2560; Fax: 966-13-860-2879; Email: SChowdhury@kfupm.edu.sa

\begin{abstract}
Water savings can be improved through reducing agricultural water consumption. The crop water requirement (CWR) depends on several factors including temperature and growing seasons. This study investigated the effects of temperature and growing seasons on CWR in Saudi Arabia. Increase in temperature by $1^{\circ} \mathrm{C}$ increased the CWR by $1.9-2.9 \%, 1.9-3.0 \%$ and $2.2-3.8 \%$ for dates, alfalfa and wheat respectively. Total CWR was estimated to be 8713 million cubic meters in 2011, which showed an increase of $1.8-2.9 \%$ for $1{ }^{\circ} \mathrm{C}$ increase in temperature. CWR for wheat was more sensitive to growing seasons than dates and alfalfa. Empirical relationship was developed to predict the effects of growing seasons on CWR for wheat while changes in CWR for dates and alfalfa were not significant. Through shifting growing seasons and minimizing the effects of temperature for the major crops, significant amount of groundwater may be saved, which can reduce the production of costly desalinated water. (C) JASEM
\end{abstract}

http://dx.doi.org/10.4314/jasem.v20i2.25

Keywords: Water resources; conservation; crop water requirement; temperature; growing seasons; policy;

\section{Introduction}

Increase in demands for food and energy crops have resulted in an increase in the demand for water around the globe (Rosegrant and Ringler, 2000; Liu et al., 2008). Crop production consumes over $80 \%$ of global freshwater supplies (Shiklomanov, 2000). The global water footprint (WFP) for crop production was 7404 billion cubic meters (BCM) per year during 19962005 , in which wheat, rice and maize consumed 1087 , 992 and $770 \mathrm{Gm}^{3} / \mathrm{yr}$ of water respectively (Mekonnen and Hoekstra, 2010). The WFP for wheat, rice and maize were in the ranges 1805-1868, 1519-2102 and $1101-1229 \mathrm{~m}^{3} /$ ton respectively (Mekonnen and Hoekstra, 2010). The agricultural water demand is affected by the types and amounts of crops, efficiency of cultivation, length and timing of growing seasons and climatic conditions (Hoekstra and Chapagain, 2007). Higher temperature can have higher evaporative demand, leading to additional water requirement for crop production (Allen et al., 1998; Chowdhury and Al-Zahrani, 2013a).

Saudi Arabia produces several crops, including wheat, alfalfa, dates, maize, vegetables, grapes and citrus (SSYB, 2012; MOA, 2012). Recent studies have indicated that the usual practices of cultivation might have detrimental effects on groundwater reserves (AlSheikh, 1998; FAO, 2009). The country has adopted a policy to reduce water withdrawals from the nonrenewable sources by reducing agricultural activities and introducing modern irrigation practices (SSYB, 2012). Past studies have projected the increase of temperature in the ranges of $1.8^{\circ}-4.1^{\circ} \mathrm{C}$ and $2.5^{\circ}-$ $5.1^{\circ} \mathrm{C}$ by 2050 and $2070-2100$ respectively, which can increase reference evapotranspiration $\left(\mathrm{ET}_{\mathrm{o}}\right)$ by 10.3 -
27.4\% (Al-Zawad, 2008; Chowdhury and Al-Zahrani, 2013a). In addition, crop growing seasons and type of crop can affect water demands (Allen et al., 1998; AlSheikh, 1998). For example, water demands for wheat, vegetables and fodder crops in Saudi Arabia were 13173,18000 and $39000 \mathrm{~m}^{3}$ per hectare respectively (Al-Sheikh. 1998). Al-Omran and Shalaby, (1992) estimated CWR for wheat, maize, tomato, citrus and dates in the Eastern and Central regions of Saudi Arabia as 883, 751, 1703, 2259 and $4021 \mathrm{~mm} / \mathrm{yr}$ respectively. In the Wadi Sirhan, Al-Jouf (Saudi Arabia), Saifuddin et al., (2004) reported CWR for alfalfa, potato and wheat as 34864, 6522 and 6473 $\mathrm{m}^{3} / \mathrm{ha} /$ season respectively. CWR for millet, wheat, maize and alfalfa in Makkah were 728, 519, 453 and 1923 mm/yr respectively (Hashim et al., 2012).

Understanding of the effects of temperature and growing seasons on CWR is important to manage water resources. This paper aims to analyze the effects of temperature and growing seasons on CWR for crops in different regions of Saudi Arabia. The growing seasons of the main crops were differed and CWR were predicted. Effects of such shifts were estimated. Empirical relationship was developed for water savings in producing wheat.

\section{MATERIALS AND METHODS}

Data Collection: Data on cultivated area and crops were obtained from the Saudi Statistical Yearbook (SSYB, 2012). Data on temperature, wind speed, sunshine periods, humidity and rainfall were obtained from the Ministry of Water and Electricity (MOWE, 2011, 2012). The crop growing seasons were obtained from literature (Alsadon, 2002; Alamoud et al., 2012; 
JADCO, 2013; Abbas, 2013). The historical data on rainfall and temperature were obtained from the CLIMWAT database of Food and Agriculture Organization (FAO, 2012). The soil type in different regions was obtained from the Saudi Geological Survey (SGS, 2012). Further details on the data can be accessed from literature (Abbas, 2013).

Predicting CWR: CROPWAT 8.0 software predicts CWR and irrigation requirements using the PenmanMonteith method (Allen et al., 1998; FAO, 2013). It can be used to evaluate farmers' irrigation practices and to estimate crop performance under rain fed and irrigated conditions. It includes standard crop and soil data in the CLIMWAT database from more than 5000 stations worldwide, which is editable using the local data (FAO, 2013). The Penman-Monteith method has been recommended by the Food and Agriculture Organization (FAO) for its reasonable prediction of

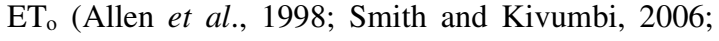
Mhashu, 2007). The actual evapotranspiration $\left(\mathrm{ET}_{\mathrm{c}}\right)$ is predicted on 10-day basis following:

$$
E T_{c}=E T_{o} \times K_{c}
$$

where, $\mathrm{ET}_{\mathrm{c}}=$ actual evapotranspiration (mm/day), $\mathrm{ET}_{\mathrm{o}}$ $=$ reference evapotranspiration $(\mathrm{mm} /$ day $) ; \mathrm{K}_{\mathrm{c}}=\mathrm{crop}$ coefficient at a specific growth stage, which varies with growth stages (Allen et al., 1998; Smith and Kivumbi, 2006). The growing period is divided into four stages: initial, development, mid-season and late season. The initial stage spans from planting date to approximately $10 \%$ of ground cover and the development stage extends from $10 \%$ ground cover to effective full cover (e.g., initiation of flowering). The mid-season stage runs from effective full cover to the start of maturity (e.g., beginning of the ageing, yellowing, leaf drop or browning of fruit) while the late season spans from the start of maturity to harvest (Allen et al., 1998). The Penman-Monteith method can be presented as:

$$
E T_{o}=\frac{0.408 \Delta\left(R_{n}-G\right)+\gamma \frac{900}{T+273} u_{2}\left(e_{s}-e_{a}\right)}{\Delta+\gamma\left(1+0.34 u_{2}\right)}
$$

where, $R_{n}=$ net radiation at crop surface $\left(\mathrm{MJ} / \mathrm{m}^{2} /\right.$ day $)$; $\mathrm{G}=$ soil heat flux density $\left(\mathrm{MJ} / \mathrm{m}^{2} /\right.$ day $) ; \mathrm{T}=$ mean daily air temperature at $2 \mathrm{~m}$ height $\left({ }^{\circ} \mathrm{C}\right) ; \mathrm{u}_{2}=$ wind speed at $2 \mathrm{~m}$ height $(\mathrm{m} / \mathrm{s}) ; \mathrm{e}_{\mathrm{s}}=$ saturation vapor pressure $(\mathrm{kPa})$; $\mathrm{e}_{\mathrm{a}}=$ actual vapor pressure $(\mathrm{kPa}) ; \Delta=$ slope of vapor pressure curve $\left(\mathrm{kPa} /{ }^{\circ} \mathrm{C}\right)$; and $\gamma=$ psychrometric constant $\left(\mathrm{kPa} /{ }^{\circ} \mathrm{C}\right)$. In this method, $\mathrm{ET}_{\mathrm{o}}$ is calculated for a reference surface, which is a hypothetical grass reference crop having crop height of $0.12 \mathrm{~m}$, shading the ground and not short of water. The weather is measured at $2 \mathrm{~m}$ (or converted to that height) above the reference surface and a fixed surface resistance of $70 \mathrm{~s}$ $\mathrm{m}^{-1}$ and an albedo of 0.23 are assumed. Further details on this method can be found in literature (Allen et al., 1998; Abbas, 2013). The effective rainfall, defined as the rainfall in excess of deep percolation and runoff, plays an important role in quantifying CWR. This water is stored in the root zone and can be used by the plants. The effective rainfall can be estimated following literature (e.g., Sheng-Feng et al., (2006); Molua and Lambi, (2006)) as:

$$
P_{\text {eff }}=P_{t o t} \frac{125-0.2 P_{t o t}}{125}
$$

where, $\mathrm{P}_{\text {eff }}=$ effective rainfall $(\mathrm{mm})$ and $\mathrm{P}_{\mathrm{tot}}=$ total rainfall $(\mathrm{mm})$. Equation 3 is valid for a rainfall of $P_{\text {tot }}$ $<250 \mathrm{~mm}$ /year. In Saudi Arabia, major parts of the country have yearly average rainfall lower than this (SSYB, 2012). The agricultural water demand is predicted as:

$Q=\sum_{i=1}^{n} A_{i}\left(E T_{c_{i}}-P_{e f f}\right) \times 10$

where, $\mathrm{Q}=\mathrm{CWR}$ for all crops within the irrigation scheme $\left(\mathrm{m}^{3} / \mathrm{day}\right) ; i=$ crop index; $\mathrm{A}_{\mathrm{i}}=$ crop area (hectare: ha); $\mathrm{ET}_{\mathrm{c} i}=$ crop evapotranspiration $(\mathrm{mm} /$ day $) ; \mathrm{P}_{\text {eff }}=$ effective rainfall $(\mathrm{mm} /$ day $) ;$ and $10=$ conversion factor from ha-mm/day to $\mathrm{m}^{3} /$ day. Further details on the Penman-Monteith method can be found in Allen et al., (1998).

\section{RESULTS AND DISCUSSIONS}

Input Data: The average temperature in 2011 varied between $11.8^{\circ}-34.5^{\circ} \mathrm{C}$ and the range was $3^{\circ}-42.8^{\circ} \mathrm{C}$. Annual rainfall varied in the range of $49.1-264 \mathrm{~mm} / \mathrm{yr}$ with an average of $123 \mathrm{~mm} / \mathrm{yr}$. Data on cultivated areas were available in literature (SSYB, 2012; Abbas, 2013). The largest area was used for cultivating wheat, followed by dates and alfalfa, while the total cultivated area was highest in Riyadh, followed by Qaseem and Al-Jouf. The growing periods and $\mathrm{K}_{\mathrm{c}}$ were obtained from literature (JADCO, 2013; Elnesr et al., 2013; Kader and Hussein, 2009; Al-Saif, 1999; Alsadon, 2002). Average wind speeds were $5.4-18 \mathrm{~km} / \mathrm{hr}$ while the relative humidity was $26-65 \%$ (FAO, 2012). The net solar radiation was $18.2-19.8 \mathrm{MJ} / \mathrm{m}^{2} /$ day, with higher in summer and lower in winter (FAO, 2012).

Crop Water Requirement (CWR): The $\mathrm{ET}_{\mathrm{o}}$ in all regions were in the range of $2.2-10.9 \mathrm{~mm} /$ day with the average of $5.0-6.9 \mathrm{~mm} /$ day. The highest $\mathrm{ET}_{\mathrm{o}}$ was in Riyadh and Al-Jouf in Jun-Jul (10.4 - 10.9 $\mathrm{mm}$ /day). In Riyadh, $\mathrm{ET}_{\mathrm{o}}$ in different months varied in the range of $3.2-10.9 \mathrm{~mm} /$ day with an average of 6.9 $\mathrm{mm}$ /day. During May-Aug, $\mathrm{ET}_{\mathrm{o}}$ were 8.5 - 10.9 $\mathrm{mm}$ /day while in Dec-Mar, $\mathrm{ET}_{\mathrm{o}}$ were in the range of 3.2 - $5.4 \mathrm{~mm} /$ day. The total CWR in 2011 was estimated to be 8713 MCM (Figure 1). Riyadh had the 
highest CWR (2802 MCM), followed by Qaseem (1426 MCM), Al-Jouf (873 MCM) and Hail (867 MCM) respectively (Figure 1).

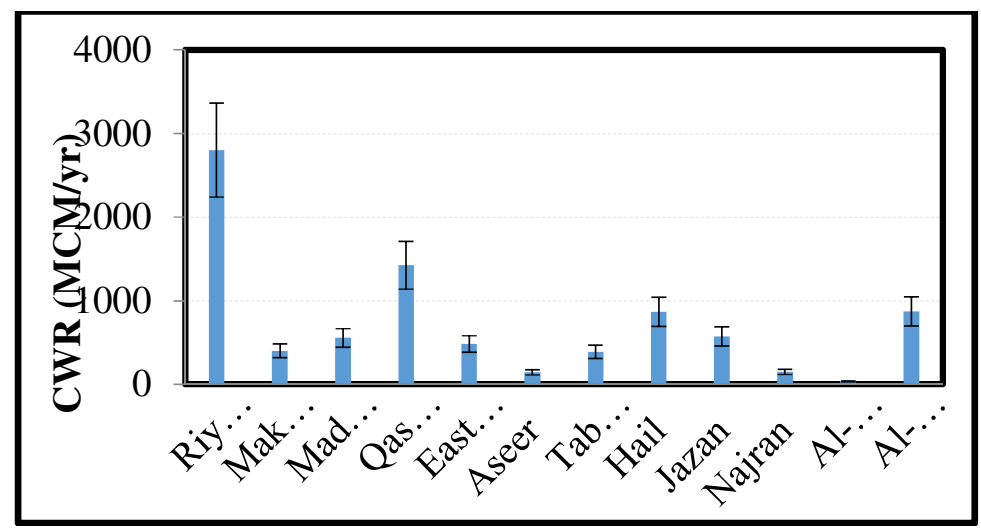

Fig 1. Predicted average CWR for each region in Saudi Arabia in 2011

The lowest CWR was estimated for Al-Baha (39 MCM). The crop and region wise distribution of CWR is shown in Table 1. Dates, alfalfa and wheat had about $75 \%$ of total CWR (dates: $40 \%$; alfalfa: $21 \%$; and wheat: $14 \%$ ). Vegetables, fruits, sorghum and maize had CWR of $10.6,4.5,6.7$ and $2.9 \%$ respectively. CWR for dates were 1032, 837 and 429 MCM in Riyadh, Qaseem and Madinah respectively. CWR for alfalfa in Riyadh, Qaseem and Al-Jouf were 989, 252 and 188 MCM respectively. For wheat, Al-Jouf had the highest CWR (476 MCM) followed by Riyadh (200 MCM). In Jazan, sorghum had CWR of 525 MCM while maize was mainly produced in Hail with CWR of 144 MCM. CWR for tomato was highest in Riyadh (60 MCM) while CWR for potato was highest in Hail (48 MCM).

Table 1. CWR for crops produced in Saudi Arabia in 2011 (MCM/year)

\begin{tabular}{lcccccccccccc}
\hline & wheat & Millet & Sorghum & Maize & Barley & Tomato & Potato & $\begin{array}{c}\text { Other } \\
\text { Vegetables }\end{array}$ & Alfalfa & Dates & Citrus & Grapes \\
\hline Riyadh & 199.8 & - & 8.3 & 23.9 & 2.1 & 59.5 & 34.5 & 371 & 988.9 & 1032 & 61.2 & 21.6 \\
Makkah & 2.6 & 5.3 & 35.6 & 4.8 & 1.4 & 20.3 & 1.4 & 58.9 & 10.4 & 225.7 & 26.2 & 9.7 \\
Madinah & 1.4 & 0.01 & - & 0.01 & 0.04 & 12.5 & 0.02 & 7.8 & 46.8 & 428.8 & 12.6 & 48 \\
Qaseem & 131.6 & - & - & 57.7 & 0.1 & 11.1 & 34 & 54.7 & 252.3 & 837.2 & 32.2 & 14.9 \\
Eastern & 135.1 & - & - & 2.4 & 0.4 & 17.2 & 1 & 35.2 & 38.8 & 242.4 & 10.4 & 2.1 \\
Region & & & & & & & & & & & & \\
Aseer & 13.5 & 0.2 & 10.2 & 1.1 & 2.2 & 11.3 & 0.4 & 5.3 & 16.3 & 77.6 & 3.5 & 4 \\
Tabouk & 117.1 & - & - & 0.2 & 0.8 & 1.1 & 20.5 & 7.7 & 150.3 & 46.1 & 27.8 & 15.9 \\
Hail & 125.5 & - & - & 143.7 & 0.9 & 6.8 & 48.1 & 28.7 & 112.7 & 367.2 & 18.8 & 14.9 \\
Jazan & 0 & 9.8 & 525.4 & 4.3 & 0.1 & 11.3 & - & 15.2 & - & 5.7 & 2.6 & - \\
Najran & 4.7 & - & - & - & 0.1 & 5.8 & 0.3 & 6.5 & 32.1 & 72 & 28.3 & 0.6 \\
Al-Baha & 2.6 & 0.01 & 0.5 & 0.7 & 0.3 & 1 & 0.04 & 1.6 & 0.8 & 28.2 & 0.6 & 2.4 \\
Al-Jouf & 476.2 & - & - & 13.4 & 2.5 & 9.2 & 14.1 & 10.7 & 187.7 & 128.9 & 12.6 & 17.4 \\
Total & 1210 & 15.3 & 580 & 252.2 & 10.9 & 167.3 & 154.3 & 603.3 & 1837 & 3492 & 236.9 & 151.5 \\
\hline
\end{tabular}

The percentile distribution of CWR are shown in Figure 2. CWR for dates had the highest percentage in Riyadh, Makkah, Madinah, Qaseem, Eastern Province, Aseer, Hail, Najran and Al-Baha. The regions of Riyadh, Qaseem, Hail and Madinah were the main contributors of dates. Riyadh was also the highest contributor of alfalfa, vegetables and fruits. In Al-Jouf, CWR for wheat was highest (54.6\%), while in Jazan, CWR for sorghum, millet and maize was 93.5\%, in which CWR for sorghum was 91.5\% (Figure 2). Al-Jouf and Riyadh were the main contributors of wheat while significant amounts of wheat were also produced in Qaseem, Eastern Province, Tabouk and Hail. Makkah, Madinah, Qaseem Tabouk, Hail, Najran and Al-Jouf produced significant quantities of fruits (citrus and grapes). 


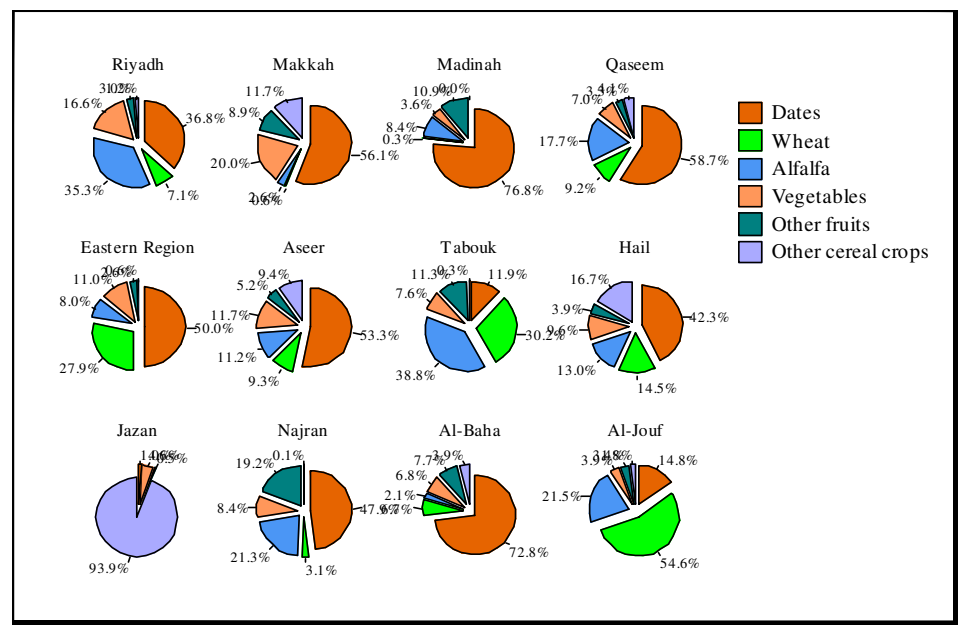

Fig 2. Distribution of CWR (\%) in different regions of Saudi Arabia; Other cereal crops are millet, sorghum, maize and barley; other fruits: citrus, grapes (excludes dates); Vegetables include all types of vegetables including tomato and potatoes

Wheat, alfalfa and dates were the major crops consuming approximately $75 \%$ of CWR. CWR for these crops were further assessed for unit production. The yields of wheat, alfalfa and dates per hectare of lands varied in the ranges of $3.0-7.2,16.2-23.1$ and $4.7-10.4$ tons respectively (SSYB, 2012). The average CWR for producing one ton of wheat, alfalfa and dates in different regions were predicted to be 1321,862 and $3232 \mathrm{~m}^{3} /$ ton respectively while their ranges were $(740-2017,669-1097$ and $1713-4316$ $\mathrm{m}^{3} /$ ton respectively. The results demonstrate wide ranges of crop yields and CWR per ton of wheat, alfalfa and dates, indicating that appropriate allocations for crops in different regions may save groundwater resources. However, better understanding is needed on water availability, cost of water transport and crop yields.
Seasonal Variability of CWR : The CWR showed seasonal and regional variability (Figure 3 ). Monthly average CWR was 726 MCM with the range of 168 1364 MCM. CWR was highest in May-Jul (1310 $1364 \mathrm{MCM} /$ month) and lowest in Nov-Jan (168 - 231 $\mathrm{MCM} /$ month). Monthly average CWR was highest in Riyadh (234 MCM) followed by Qassim (119 MCM), Al-Jouf (73 MCM) and Hail (72 MCM) while the lowest CWR was in Al-Baha (3.0 MCM). In Riyadh, CWR was highest in Jun-Jul (489 - 494 MCM/month) while the lowest CWR was in Jazan during Oct-Jan (1.3 - $2.1 \mathrm{MCM} / \mathrm{month})$. In Qaseem, CWR was highest in May-Jul (217 - $223 \mathrm{MCM} /$ month) and lowest in Dec-Jan (24-33 MCM/month). In Al-Jouf, wheat was the main crop and it was grown in Jan-May, leading to higher CWR in Mar-Apr (164 - 205 $\mathrm{MCM} / \mathrm{yr})$.

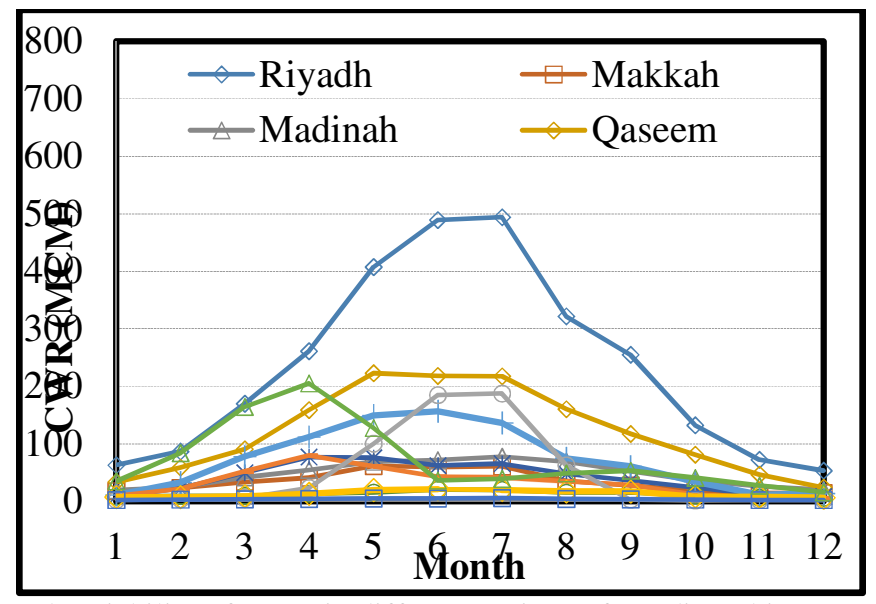

Fig 3. Seasonal variability of CWR in different regions of Saudi Arabia [1: Jan - 12: Dec]

Overall, CWR in summer (e.g., May-Jul) were much higher than in winter (e.g., Nov-Feb). Higher CWR in summer was possibly due to large amounts of crops produced in summer, low rainfall, growing stage with higher $\mathrm{K}_{\mathrm{c}}$ and higher temperature. Production of dates and alfalfa in Riyadh can be the examples. The growing periods of these crops were Dec-Nov and OctSep respectively while the mid-season of growing 
stage (e.g., higher values of $\mathrm{K}_{\mathrm{c}}$ ) was in summer. Interaction of $\mathrm{ET}_{\mathrm{o}}$ at higher temperature and higher $\mathrm{K}_{\mathrm{c}}$ increased CWR (Eq. 1). Shifting of the mid-season growing stage from summer to a lower $\mathrm{ET}_{\mathrm{o}}$ season may reduce $\mathrm{CWR}$ and reduce water extraction from the non-renewable sources. However, interaction effects of $\mathrm{ET}_{\mathrm{o}}$ at higher temperature and higher $\mathrm{K}_{\mathrm{c}}$ needs better understanding to avoid any negative effect (e.g., crop yields, crop quality, etc.).

Effects of Temperature: Effects of temperature were investigated by increasing temperature in the range of $1^{\circ}-5^{\circ} \mathrm{C}$ and keeping the other factors constant. The total CWR was increased from 8713 MCM to 9716
MCM for $5^{\circ} \mathrm{C}$ increase in temperature, which showed an increase in CWR by $2.3 \% /{ }^{\circ} \mathrm{C}$. In different regions, rate of increase in CWR was estimated to be in the range of $1.8-2.9 \%$ for $1{ }^{\circ} \mathrm{C}$ increase in temperature. The increase in CWR for temperature increase in different regions are shown in Figure 4 . For $1^{\circ} \mathrm{C}, 3^{\circ} \mathrm{C}$ and $5^{\circ} \mathrm{C}$ increase in temperature, CWR increase were estimated to be 199, 606 and 1002 MCM respectively (Figure 4). Among different regions, Riyadh showed the highest increase in CWR (57.7 MCM), followed by Qaseem (31.4 MCM), Al-Jouf (24.9 MCM) and Hail (20.3 MCM) respectively (Figure 4).

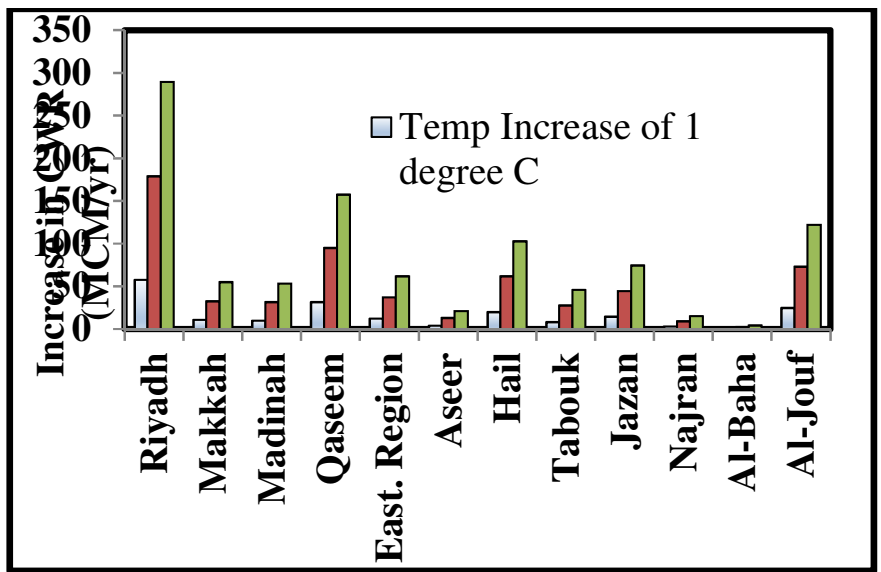

Fig 4. Effects of temperature increase on crop water requirements in different regions

Some past studies have reported possible increase in temperature in the range of $1.8-5.1^{\circ} \mathrm{C}$ by the end of this century. The Intergovernmental Panel on Climate Change (IPCC) have also reported similar increase in temperature in the Arabian Peninsula (IPCC, 2007). Such an increase may increase the total CWR by $4.1-$ $12 \%$ for the same level of agricultural production. With respect to crops, wheat, dates and alfalfa were the main crops. Effects of temperature change on CWR for these crops were investigated further. Average increase of CWR for dates, alfalfa and wheat were 2.3, 2.3 and $2.8 \%$ for $1{ }^{\circ} \mathrm{C}$ respectively while their ranges were $1.9-2.9 \%, 1.9-3.0 \%$ and $2.2-3.8 \%$ respectively. In this study, CWR for 1 hectare (ha) of dates, alfalfa and wheat producing lands were 23896, 19742 and $6467 \mathrm{~m}^{3}$ respectively, which were consistent to past studies (Al-Sheikh, 1998; Al-Omran and Shalaby, 1992; Saifuddin et al., 2004). Increase in temperature can further increase CWR. In addition, temperature increase may also affect the crop yields, which may change CWR per unit production. Better understanding of the effects of temperature on crop yields may provide further insights.

Effects of Growing Period: The main three crops were wheat, dates and alfalfa, which were produced in 196, 162 and 102 thousand ha of cultivated lands respectively. The $4^{\text {th }}$ largest land area is for sorghum
(84 thousand ha) (SSYB, 2012). The growing season of wheat is Nov-May (Mustafa et al., 1989) while few regions start wheat planting during January (Saifuddin et al., 2004; Almisnid, 2005). Wheat needs approximately 130 days from planting to harvesting, meaning that wheat planted in Jan is harvested in Apr - May, while $\mathrm{ET}_{\mathrm{o}}$ in Apr-May is relatively higher than Nov-Mar. Five scenarios of wheat growing periods: $S_{1}$ (Jan 01 - May 10); $S_{2}$ (Dec 15 - Apr 23); $S_{3}$ (Dec $01-$ Apr 09); $S_{4}$ (Nov 15 - Mar 24); and $S_{5}$ (Nov 01-Mar 10) were investigated. Table 2 shows the CWR for wheat in different growing seasons $\left(S_{1}-S_{5}\right)$. The current practice had CWR for wheat of 1209 MCM while the $S_{1}, S_{2}, S_{3}, S_{4}$ and $S_{5}$ scenarios had CWR of 1046, 870, 757, 672 and 638 MCM respectively. The data showed an exponential relationship between CWR and planting dates, which were represented as:

$Y=1192.9 e^{-0.00934 X}$

Where, $Y=$ Overall CWR for wheat (MCM/yr); $X=$ Shift of planting date (day) from Jan 15 to an earlier date. This is to be noted that equation 5 was obtained through considering Jan 15 as the current planting date and maximum shifting period of 75 days earlier (e.g., Nov 01). The regional analyses also showed exponential relationships. 
Table 2. CWR for wheat in different regions at different growing periods

\begin{tabular}{lllllll}
\hline Regions & Current & $\mathbf{S}_{\mathbf{1}}$ & $\mathbf{S}_{\mathbf{2}}$ & $\mathbf{S}_{\mathbf{3}}$ & $\mathbf{S}_{\mathbf{4}}$ & $\mathbf{S}_{\mathbf{5}}$ \\
\hline Riyadh & 199.8 & 172.6 & 146.1 & 131.5 & 120.7 & 117.4 \\
Makkah & 2.6 & 2.4 & 2.3 & 2.1 & 2 & 1.9 \\
Madinah & - & - & - & - & - & - \\
Qaseem & 131.6 & 109.8 & 88 & 75.2 & 68.6 & 70 \\
Eastern & 135.1 & 113.7 & 92.4 & 78.3 & 68.5 & 67.6 \\
region & 13.5 & 12.8 & 12.2 & 11.8 & 11.8 & 12.1 \\
Aseer & 125.5 & 108.3 & 90 & 77.8 & 65.2 & 56.5 \\
Hail & 117.1 & 102.8 & 85.7 & 73.3 & 63.2 & 58.2 \\
Tabouk & - & - & - & - & - & - \\
Jazan & 4.7 & 4.4 & 4 & 3.8 & 3.8 & 3.9 \\
Najran & 2.6 & 2.4 & 2.2 & 2.1 & 2 & 2 \\
Al-Baha & 476.2 & 417 & 347.5 & 301.1 & 265.7 & 248.7 \\
Al-Jouf & 1208.7 & 1046.2 & 870.4 & 757 & 671.5 & 638.3 \\
Total & & & & &
\end{tabular}

Current: Jan 15 - May 24; $\mathrm{S}_{1}$ : (Jan 01 - May 10); $\mathrm{S}_{2}$ : (Dec 15 - Apr 23); $\mathrm{S}_{3}$ : (Dec 01 -Apr 09); $\mathrm{S}_{4}$ : (Nov 15 - Mar 24); $\mathrm{S}_{5}$ : (Nov $01-$ Mar 10)

Dates is the main crop in nine regions (Figure 2). Riyadh, Madinah, Makkah and Najran have the growing cycle of Jan-Dec (Alamoud et al., 2012). For Dec 01-Nov 30 cycle, CWR in Riyadh was 1032 MCM. Four additional scenarios of growing cycles: $\mathrm{S}_{1}$ : (Nov 15 - Nov 14); $\mathrm{S}_{2}$ : (Nov 01 - Oct 31); $\mathrm{S}_{3}$ : (Dec 15 -Dec 14); and $\mathrm{S}_{4}$ : (Jan $01-$ Dec 31) had CWR of 1037, 1044, 1022 and $1010 \mathrm{MCM}$ respectively. In Qaseem, growing season was Oct-Sep. Four additional scenarios: $S_{1}$ (Sep 15 - Sep 14); $S_{2}$ (Sep 01 - Aug 31); $\mathrm{S}_{3}$ (Oct 15 -Oct 14); and $\mathrm{S}_{4}$ (Nov 01 - Oct 31) were also assessed. CWR for the current cycle and $\mathrm{S}_{1}-\mathrm{S}_{4}$ were $837,832,832,834$ and 835 MCM respectively. In the other regions, shifts in growing cycles were also investigated. However, changes in CWR were insignificant in these scenarios.

Alfalfa is primarily produced in Riyadh, Qaseem, AlJouf and Tabouk. In Riyadh, current growing period (Oct 01-Sep 30) had CWR of 989 MCM. Four additional scenarios with growing cycles of $S_{1}$ : (Sep 15 - Sep 14); $\mathrm{S}_{2}$ : (Sep 01 - Aug 31); $\mathrm{S}_{3}$ : (Oct 15 -Oct 14); and $S_{4}$ : (Nov $01-$ Oct 31 ) had CWR of 978,952 ,

Policy Implications on Water Savings: The Ministry of Economy and Planning (MOEP), Saudi Arabia reported that agricultural water use in 2009 was 15464 MCM, which was projected to be $12794 \mathrm{MCM}$ in 2014 , indicating a decrease of 3.7\%/yr (MOEP, 2010). At this rate, water supply for agriculture in 2011 was 14300 MCM, which was 5587 MCM more than the estimated CWR. It can be noted that few seasonal crops might have been produced in different regions (e.g., greenhouse cultivation), which were not included in this study, mainly due to data unavailability (SSYB, 2012). These crops need to be included to better estimate water loss. In Saudi Arabia, the type of soil is sandy and sandy loam (SGS, 2012) with high conductivity. Higher temperature in summer
996 and 986 MCM respectively. However, Qaseem region did not show significant change in CWR in these scenarios. Sorghum is the main crop in Jazan, which had a growing cycle of Apr-Aug. For growing period of Apr 15 - Aug 17 (125 days), CWR was 525 MCM. For the shifted growing periods of $S_{1}$ : (Apr 01 - Aug 03); $S_{2}$ : (Feb 01 - June 05); $S_{3}$ : (Jan 15 -May 19); $\mathrm{S}_{4}$ : (Jul 01 - Nov 02); and $\mathrm{S}_{5}$ : (Jul 15 - Nov 16), CWR were 518, 457, 430, 490 and $468 \mathrm{MCM}$ respectively. In context to total CWR in the country, shift of growing seasons was performed for the main crops in each region (Table 3 ). Total CWR for shifted growing seasons was estimated to be 7982 MCM, which was $731 \mathrm{MCM}$ less than the current practice (Table 3). Water savings was estimated to be the highest in Al-Jouf, followed by Riyadh, Qaseem and Hail. Shifting of the planting date of wheat to Nov 01 might save 572 MCM of water, which was $78 \%$ of the total water savings (Table 2). For the shifted growing periods of dates, alfalfa, sorghum and grapes, 37, 61, 61 and 1 MCM of water could be saved. Future study should look into the implications of a shift on crop yields.

might also be responsible for increased water consumption in summer. In addition, the months of mid-season growing stages could have played significant role on CWR. Higher $\mathrm{K}_{\mathrm{c}}$ for dates, alfalfa and wheat were noted for May-Oct, May-Sep and AprMay respectively. In these months, $\mathrm{ET}_{\mathrm{o}}$ were much higher and $\mathrm{K}_{\mathrm{c}}$ were $0.95,0.95$ and 1.15 respectively, which have resulted in higher levels of CWR. Shifting the mid-season growing stages to the months with lower $\mathrm{ET}_{\mathrm{o}}$ could save groundwater. With few hypothetical scenarios, possible water savings was estimated. To save groundwater, Saudi Arabia has taken few initiatives. Agricultural activity is being reduced (MOEP, 2010; SSYB, 2012; CSIS, 2011). It is to be noted that wheat is the main crop for food 
security in Saudi Arabia and the $3^{\text {rd }}$ largest water consuming crop while the $1^{\text {st }}$ and $2^{\text {nd }}$ crops were dates and alfalfa respectively (SSYB, 2012). This study recommends using food security as a criterion under current regional political situation for future decision analysis on controlling agricultural activities.

\begin{tabular}{|c|c|c|c|c|c|c|}
\hline \multirow[t]{2}{*}{ Region } & \multirow{2}{*}{$\begin{array}{l}\text { Shifted } \\
\text { Crops }\end{array}$} & \multicolumn{3}{|c|}{ Growing Periods } & \multicolumn{2}{|c|}{ CWR (MCM) } \\
\hline & & $\begin{array}{l}\text { Before } \\
\text { shifting }\end{array}$ & After shifting & $\begin{array}{l}\text { Before } \\
\text { shifting }\end{array}$ & $\begin{array}{l}\text { After } \\
\text { shifting }\end{array}$ & $\begin{array}{l}\text { Water } \\
\text { savings }\end{array}$ \\
\hline \multirow[t]{3}{*}{ Riyadh } & Wheat & $\operatorname{Jan} 15^{\circ}$ & Nov 01 & $2802.5^{\circ}$ & $2661.4^{\circ}$ & 141.1 \\
\hline & Alfalfa & Oct 01 & Sep 01 & & & \\
\hline & Dates & Dec 01 & Jan 01 & & & \\
\hline \multirow{2}{*}{ Makkah } & Dates & Aug 01 & Sep 01 & 402.3 & 400.3 & 2 \\
\hline & Wheat & Jan 15 & Nov 01 & & & \\
\hline \multirow[t]{3}{*}{ Madinah } & Dates & Oct 01 & Nov 01 & 558 & 552.8 & 5.2 \\
\hline & Grapes & Mar 01 & Apr 01 & & & \\
\hline & Alfalfa & Oct 01 & Nov 01 & & & \\
\hline \multirow[t]{3}{*}{ Qaseem } & Wheat & Jan 15 & Nov 01 & 1425.9 & 1351.5 & 74.4 \\
\hline & Alfalfa & Oct 01 & Sep 01 & & & \\
\hline & Dates & Oct 01 & Sep 01 & & & \\
\hline \multirow[t]{2}{*}{ Eastern Region } & Wheat & Jan 15 & Nov 01 & 485 & 415.7 & 69.3 \\
\hline & Dates & Aug 01 & Sep 01 & & & \\
\hline \multirow[t]{4}{*}{ Aseer } & Wheat & Jan 15 & Nov 01 & 145.6 & 139.9 & 5.7 \\
\hline & Dates & Aug 01 & Sep 01 & & & \\
\hline & Alfalfa & Oct 01 & Sep 01 & & & \\
\hline & Sorghum & Apr 15 & Jan 15 & & & \\
\hline \multirow[t]{3}{*}{ Tabouk } & Wheat & Jan 15 & Nov 01 & 390.6 & 327.4 & 63.2 \\
\hline & Alfalfa & Oct 01 & Nov 01 & & & \\
\hline & Dates & Oct 01 & Nov 01 & & & \\
\hline \multirow[t]{3}{*}{ Hail } & Wheat, & Jan 15 & Nov 01 & 867.3 & 793 & 74.3 \\
\hline & Alfalfa & Oct 01 & Sep 01 & & & \\
\hline & Dates & Oct 01 & Nov 01 & & & \\
\hline Jazan & sorghum & Apr 15 & Jan 15 & 574.3 & 516.8 & 57.5 \\
\hline \multirow[t]{4}{*}{ Najran } & Wheat, & Jan 15 & Nov 01 & 150.4 & 147.9 & 2.5 \\
\hline & Alfalfa & Oct 01 & Sep 01 & & & \\
\hline & Dates & Oct 01 & Nov 01 & & & \\
\hline & Citrus & Mar 01 & Mar 15 & & & \\
\hline \multirow{2}{*}{ Al-Baha } & Wheat & Jan 15 & Nov 01 & 38.8 & 38 & 0.8 \\
\hline & Dates & Aug 01 & Sep 01 & & & \\
\hline \multirow[t]{4}{*}{ Al-Jouf } & Wheat & $\operatorname{Jan} 15$ & Nov 01 & 872.7 & 637.2 & 235.5 \\
\hline & Dates & Apr 01 & Mar 01 & & & \\
\hline & \multirow{2}{*}{\multicolumn{3}{|c|}{ Total }} & & & \\
\hline & & & & 8713.4 & 7981.9 & 731.5 \\
\hline
\end{tabular}

In Saudi Arabia, most of the agricultural farms practice open irrigation, which could have led to higher evaporative and conductive losses. The advanced irrigation practices (e.g., sprinkler irrigation, green house, etc.) might reduce the overall losses. In many countries, greenhouse cultivation is becoming popular, which can reduce the evaporative losses. Although Saudi Arabia has started greenhouse cultivation for few vegetables and fruits, these are still at limited scale (SSYB, 2012).

Another option is relocating crops from higher CWR regions to lower CWR regions. Using crop yields (FAO, 2012), CWR for dates, alfalfa and wheat were estimated to be in the ranges of $1713-4316,669-$ 1097 and $740-2017 \mathrm{~m}^{3} /$ ton respectively. The Eastern Province, Aseer and Hail were the most water efficient regions for dates $\left(1713 \mathrm{~m}^{3} /\right.$ ton$)$, alfalfa $\left(669 \mathrm{~m}^{3} / \mathrm{ton}\right)$ and wheat $\left(740 \mathrm{~m}^{3} /\right.$ ton) respectively. Although Riyadh was not on top of the water efficient regions (CWR for dates, alfalfa and wheat were 3975, 982 and 1265 $\mathrm{m}^{3} /$ ton respectively), Riyadh produced the highest fractions of dates and alfalfa and the $2^{\text {nd }}$ highest fraction of wheat (SSYB, 2012). Shifting the production of dates, alfalfa and wheat from Riyadh to Eastern Province, Aseer and Hail may conserve 2262, 313 and $525 \mathrm{~m}^{3} /$ ton of water respectively. Strategic planning on relocation of agricultural activities might save groundwater for future. However, relocation of agricultural activities is not straightforward. Such a strategic move needs comprehensive study on crop yields, technical feasibility, water availability, financial burdens, and most importantly, the social aspects.

Many countries are using treated wastewater (TWW) for agriculture. While reuse of TWW augments water supplies for agriculture, contribution of TWW to agricultural water demands in Saudi Arabia needs further attention. In 2011, wastewater generation was little more than $2000 \mathrm{MCM}$ while $1260 \mathrm{MCM}$ was treated and approximately $325 \mathrm{MCM}$ was recycled for reuse (MOEP, 2010; MOWE, 2011, 2012). The low reuse of TWW might be due to the lack of infrastructure for collection, treatment and recycling of wastewater (MOEP, 2010; Chowdhury and Zahrani, 
2013b). If the total TWW could be collected and recycled, that would satisfy less than $11 \%$ of total agricultural water supplies in 2011 (MOEP, 2010). The agricultural fields are generally far away from treatment plants. Cost of TWW transportation to the agricultural fields might be significant. It is essential to explore other options for the best use of TWW and to identify the strategy for the maximum benefit of reusing TWW in Saudi Arabia. As an example, approximately $2650 \mathrm{MCM}$ of water was needed in the domestic sector in which approximately $1600 \mathrm{MCM}$ was supplied by the desalination plants. Significant fractions of the domestic water supplies were used for washing machine and toilet flushing. On average, one toilet flush needs 5-13 liters of water while a load of washing machine consumes 57-151 liters of water (Waterwise, 2015). Approximately $15 \%$ and $30 \%$ of total domestic water is used for washing machine and toilet flushing respectively (Waterwise, 2015). There is an opportunity to explore the option of reusing TWW for washing machine and toilet flushing. The domestic wastewater can be collected and treated in the community/satellite treatment plants, which can be transported back to the community. This is likely to avoid the collection of large amounts of wastewater and long transportation, which can keep the cost minimal. The total cost (e.g., capital, treatment, transportation and maintenance cost) of reusing tertiary TWW were in the range of US\$ $0.83-2.03 / \mathrm{m}^{3}$ with an average of US $\$ 1.43 / \mathrm{m}^{3}$. The overall cost for using desalinated water (including transportation cost) were in the range of US\$ $1.31-2.37 / \mathrm{m}^{3}$ with an average of US $\$ 1.84 / \mathrm{m}^{3}$ (Kajenthira et al., 2011; Chowdhury and Al-Zahrani, 2013b). Reuse of TWW can save about US\$ $0.41 / \mathrm{m}^{3}$ of water and approximately $45 \%$ of domestic water demands can be supplemented ( $\cong 1200 \mathrm{MCM} /$ year). At this rate, reuse of TWW may save approximately US\$ 492 million $\left(=1200 \times 10^{6} \times 0.41\right)$ per year. This system can save the environment from pollution related to wastewater discharges into the wadies, sand dunes and the Arabian Gulf and Red Sea. There is a need to perform pilot scale feasibility study in this direction. The remaining TWW can also be reused for local agricultural fields and/or landscaping activities. Future study may look into this option.

Conclusions: This study demonstrated implications of temperature and growing seasons on CWR. CWR for wheat showed exponential decay pattern when planting date were shifted from Jan to an earlier date, with the maximum shifting period of 75 days (e.g., Nov). Further investigation is needed on the effects of shifting of growing seasons for the main crops, relocation of crops from higher CWR to lower CWR areas, effects of relocation on crop yields, technical feasibility, water availability and cost of water transportation to the agricultural areas. Several factors (e.g., historical trends, labor availability, rainfall, crop yields, market demand and price, groundwater availability and/or permits) can be the major barriers for such shift. Future study is needed to better understand the effects of the noted factors.

Acknowledgements: The authors would like to acknowledge the support provided by the Deanship of Scientific Research (DSR) at King Fahd University of Petroleum \& Minerals (KFUPM) for funding this work through project No. RG 1410-1 \& 2.

\section{REFERENCES}

Abbas, A (2013). Implications of climate change on crop water requirements in Saudi Arabia. M.S. Thesis. King Fahd University of Petroleum and Minerals (KFUPM), Saudi Arabia.

Alamoud, AI; Mohammad, FS; Al-Hamed, SA; Alabdulkader, AM (2012). Reference evapotranspiration and date palm water use in the kingdom of Saudi Arabia. J. Agricultural Sciences and Soil Sciences. 2(4): 155-169.

Allen, RG;, Pereira, LS; Raes, D; Smith, M (1998). Crop evapotranspiration: Guidelines for computing crop water requirements - FAO Irrigation and Drainage Paper No. 56. Food and Agricultural Organization of the United Nations, Rome, Italy $300 \mathrm{pp}$

Almisnid, A (2005). Climate change and water use for irrigation: a case study in the Gassim area of Saudi Arabia. PhD thesis, University of East Anglia

Al-Omran, AM; Shalaby, AA (1992). Calculation of water requirements for some crops in the eastern and central regions of the Kingdom of Saudi Arabia, J. coll. Agric. King Saud Univ. 4: 97-114.

Alsadon AA (2002). The best planting dates for vegetables crops in Saudi Arabia: Evaluation of compatibility between the dates planned based on Heat Units and dates suggested from the regional offices of the Ministry. Agricultural Science 14(1): 75-79.

Al-Saif, AM (1999). Evaluation and Selection of Some Local Grape Cultivars Grown in Riyadh Region, Saudi Arabia. Master's thesis, King Saud University, Riyadh, Saudi Arabia

Al-Sheikh, HMH (1998). Country case study: Water policy reform in Saudi Arabia. Proceedings of the second expert consultation on national water policy reform in the Near East. Food and Agriculture Organization, Regional Office for the Near East, Cairo, 19 p

Al-Zawad, FM (2008). Impacts of Climate Change on Water Resources in Saudi Arabia. The $3^{\text {rd }}$ International Conference on Water Resources and 
Arid Environments and the 1st Arab Water Forum, Riyadh, Saudi Arabia

Chowdhury, S; Al-Zahrani, M (2013a) Implications of climate change on water resources in Saudi Arabia, Arab J Sci. Eng., 38: 1959-1971.

Chowdhury, S; Al-Zahrani, M (2013b). Reuse of treated wastewater in Saudi Arabia: an assessment framework. Journal of Water Reuse and Desalination, 3(3): 297 - 314.

CSIS (Centre for Strategic and International Studies) (2011). Water and National Strength in Saudi Arabia. http://csis.org/program/middle-eastprogram Accessed Sep 2015

Elnesr, MN, Alazba, AA; Alsadon, AA (2013). An arithmetic method to determine the most suitable planting dates for vegetables. Computer and Electronics in Agriculture 90: 131-143.

FAO (Food and Agriculture Organization) (2009). Irrigation in the Middle East region in figures. FAO Water Reports 34, Rome

FAO (Food and Agriculture Organization). (2012). CLIMWAT: A climatic database for irrigation planning and management, FAO. http://www.fao.org/nr/water/infores_databases.ht $\underline{\mathrm{ml} \text { Accessed Sep } 2012}$

FAO (Food and Agriculture Organization). (2013). CROPWAT software, Food and Agriculture Organization, Land and Water Division; Available

at: http://www.fao.org/nr/water/infores_databases_c ropwat.html Accessed May 2014

Hashim, MAA; Siam, N; Al-Dosari, A; Asl-Gaadi, KA; Patil, VC; , Tola, EHM; Rangaswamy, M; Samdani, MS. (2012). Determination of Water Requirement and Crop water productivity of Crops Grown in the Makkah Region of Saudi Arabia. Australian Journal of Basic and Applied Sciences, 6(9): 196-206.

Hoekstra, AY; Chapagain, AK (2007). Water footprints of nations: Water use by people as a function of their consumption pattern. Water Resources Management. 21(1): 35-48.

IPCC (Intergovernmental Panel on Climate Change), (2007). Climate Change: The Physical Science Basis." Contribution of Working Group I to the Fourth Assessment Report of the Intergovernmental Panel on Climate Change. In: Solomon, S; Qin, D; Manning, M; Chen, Z; Marquis, M; Averyt, KB; Tignor, M; Miller, HL (Eds.). Cambridge University Press, Cambridge, United Kingdom/New York, NY, USA, 2007 b.
JADCO (Al-Jouf Agricultural Development Company) (2013). Al-Jouf, Saudi Arabia, Available http://www.aljouf.com.sa/en_default.aspx, Accessed on Jan 2013.

Kader, AA; Hussein, A (2009). Harvesting and postharvest handling of dates. ICARDA, Aleppo, Syria. 15 pp

Kajenthira, DA; Anadon, LD; Siddiqqi, A (2011). A new case for wastewater reuse in Saudi Arabia: Bringing energy into water equation. The Dubai Initiative - Policy Brief, Belfer Center for Science and International Affairs.

Liu. J; Yang, H; Savenije, HHG (2008). China's move to higher-meat diet hits water security, Nature, 454: 379-379.

Mekonnen, MM; Hoekstra, AY (2010). The green, blue and grey water footprint of crops and derived crop products, Value of Water Research Report Series No. 47, UNESCO-IHE, Delft, the Netherlands

Mhashu, SV (2007). Yield response to water function and simulation of deficit irrigation scheduling of sugarcane at estate in Zimbabwe using CROPWAT 8.0 and CLIMWAT 2.0, Master thesis, University of Florence

MOA (Ministry of Agriculture) (2012). Agriculture Statistical year book, Saudi Arabia. http://www.moa.gov.sa/public/portal Accessed Oct 2012

MOEP (The Ministry of Economy and Planning) (2010). The ninth development plan, Ministry of Economy and Planning, Saudi Arabia. Legal Deposit No. 16/0694

MOWE (Ministry of Water and Electricity). (2011) Annual Report, Riyadh, Saudi Arabia [Online]. Available http://www.mowe.gov.sa/ENIndex.aspx Accessed May 2014

MOWE (Ministry of Water and Electricity) (2012). Annual Report, Riyadh, Saudi Arabia [Online]. Available at: http://www.mowe.gov.sa/ENIndex.aspx Accessed May 2014.

Molua, EL; Lambi, CM (2006). Assessing the impact of climate on crop water use and crop water productivity: the CROPWAT Analysis of Three Districts in Cameroon, p. 1-44 
Mustafa, MA; Akabawi, KA; Zoghet, MF (1989). Irrigation water requirements of wheat in the life zones of Saudi Arabia. J. Arid Environ. 17: 349354

Rosegrant, MW; Ringler, C (2000). Impact on food security and rural development of transferring water out of agriculture, Water Policy. 1(6): 567586

Saifuddin, A; Al-Rumikhani, YA; Latif, MS (2004). Use of remote sensing and agrometeorology for irrigation management in arid lands: a case study from northwestern Saudi Arabia. Journal of Environmental Hydrology 12(9): 1-14.

SGS (Saudi Geological Survey) (2012). Facts and Figures: First published in Saudi Arabia. Available at: http://www.sgs.org.sa/English/Pages/default.aspx Accessed May 2014

Sheng-Feng, K., Shin-Shen, H. \& Chen-Wuing, L (2006). Estimation irrigation water requirements with derived crop coefficients for upland and paddy crops in ChiaNan Irrigation Association, Taiwan. Agricultural Water Management 82(6): 433-451.

Shiklomanov, IA (2000). Appraisal and assessment of world water resources. Water International 25(1): 11-32.

Smith, M; Kivumbi, D (2006). Use of the FAO CROPWAT model in deficit irrigation studies. FAO (Food and Agriculture Organization), Rome, Italy; Heng, L. K., Joint FAO/IAEA Division, International Atomic Energy Agency, Vienna, Austria.

SSYB (Saudi Statistical Year Book) (2012). Ministry of Economy and Planning. Central Department of Statistics and Information. Available at: http://www.moh.gov.sa/en/Ministry/Statistics/bo ok/Pages/default.aspx Accessed Sep 2014.

Waterwise (2015). Save Water. Available at: http://www.waterwise.org.uk/pages/indoors.html. Accessed Sep 2015 